interest in human suffering appropriate to the specialty; it may also reflect the turmoil of psychiatrists in training. Whether this is a cause or a result of choosing a psychiatric career remains unclear. It would be interesting to compare these findings with trainees elsewhere or in other fields.

We are grateful to all those replying to the survey and hope that non-responders may be tempted to move on from literature they felt unable to admit to.

PaUl Harrison

Littlemore Hospital, Oxford

Alexandra DaY

\section{Sir Charles Symonds}

\section{DeAR SIRS}

I much enjoyed Sidney Crown's Proustian jaunt down Memory Lane (Bulletin, July 1988, 12, 263266) which, despite his protestations, is 'history', and most important history at that.

However, I think he has been a little unfair to Sir Charles Symonds. I had the privilege of working under Sir Charles for well nigh three years at RAF Central Medical Establishment, London, where he enjoyed the exalted rank of Air Vice Marshal. Initially, I agree, he did present as a cold intellectual; but this was a facade. He was in fact a shy man, the more one got to know him the more one was able to penetrate the facade and discover the very human being who lay beneath.

He was ever-loyal to his protégés, and up to the time of his death he would write to me in his own hand commenting about a paper or a letter I had published in the medical press.

101 College Road

HenRy R. Rollin

Epsom, Surrey

\section{Information leaflets for patients}

\section{DeAR SiRs}

I am writing to you on behalf of the Medication Working Party of Camberwell Health Authority's Mental Health Care Group. We are planning to research and develop information leaflets, (which are to be given to patients), on their psychotropic medication. We would like to hear from other groups of researchers involved in this field or those who are interested in this kind of development.

Medication Working Party

JANET CARRICK

The Dulwich Hospital, North Wing

St Francis' Road

London SE22 8DF

\section{Code of Practice and compulsory} admissions

\section{DEAR SIRS}

I wish to contribute to the debate on management of severe psychiatric disturbance under the 1983 Mental Health Act.

My colleagues and I continue to encounter ASWs who induce patients to acquiesce to informal admission. The ASW can do this with confidence if the necessary two doctors have already completed, or state their readiness to complete, recommendations for compulsory admission. When admission takes place in this way, ward staff experience considerable difficulty in establishing rapport with an informal, but reluctant, patient. In my experience, reassessment with a view to compulsory detention usually takes place at a later date, sometimes with an unnecessary crisis requiring the use of emergency holding powers and always with detriment to staffpatient relationships.

Both the 1985 Mental Health Act Commission Draft Code of Practice and the 1987 DHSS Code proscribed the use of coercion to induce a patient to acquiesce to informal admission by threats of compulsory admission if he does not comply (section 1.15.4 and paragraph 30 respectively). The DHSS Code went further; paragraph 28 observed that "although the patient may indicate willingness to be admitted informally, in a very few cases compulsory admission may still need to be considered under certain circumstances".

Both Codes invited a response. In response to the MHAC Code, the BMA supported the advice against coercion. The BMA also made the following suggestion about when the ASW does not wish to make an application despite medical recommendations (section 1.17.7): "The duty of the ASW to inform the nearest relative in writing when she/he does not agree to a compulsory admission should be extended to informing the doctor who made the initial request in writing." This suggestion was not taken up in the DHSS Code.

In response to the DHSS Code, the College reiterated the BMA's suggestion, recommending that paragraph 41, should read, "the ASW should also provide his reasons in writing to the other professionals involved, discuss alternative courses of action and consider what continuing social work help may be needed by the patient and the family. The social worker should make clear the relative's own rights to make an application." ${ }^{2,3}$ (Bold print used in the original College response to indicate additions.)

The College also accepted paragraph 30 unaltered and recommended that paragraph 28 include an explanation of what should be regarded as "certain circumstances". One of the circumstances the College suggested covered the contingency of coercion. 
So these are the developments so far. There have been two Codes of Practice. Each has advised against coercion of patients into informal admission. The College and the BMA, presumably because of awareness of field experience, have not only endorsed this advice but seen it as inadequate to deal with the delicate situation that arises when the medical and social work opinions differ. They have recommended further safeguards against coercion.

In the most recent development, I understand that DHSS has abandoned the 1987 Code of Practice in the form that we have seen. A new Code is hurriedly to be written and placed before Parliament without further consultation.

I am concerned that this is just one of several areas of practice where an ill-conceived Code of Practice may do lasting damage to relationships between those who have to work together within it.

\section{Glenside Hospital}

Stapleton, Bristol

ANTHONY White

\section{References}

'British Medical Association (1987) The Mental Health Act 1983 Draft Code of Practice. Bulletin of the Royal College of Psychiatrists 11, 63-66.

${ }^{2}$ Royal College OF Psychiatrists (1988) Mental Health Act 1983: Revised Draft Code of Practice. Bulletin of the Royal College of Psychiatrists, 12, 68

3 - (1987) Comments on the DHSS Code of Practice.

\section{An alternative use for dothiepin}

\section{DeAR SIRS}

We report the anecdotal case of a 40 year-old woman, Mrs AS., who is receiving anti-depressant therapy and attending our clinic. One night, having returned home from a social evening, during which she had taken a quantity of alcohol, Mrs S refrained from taking her nocturnal dose of dothiepin. She had been troubled for a length of time by the presence of a mouse in her kitchen, so she opened a $25 \mathrm{mg}$ capsule and placed the contents on a piece of cheese which she left out in the kitchen in the hope that the mice might ingest it.

The following morning she discovered the body of the mouse beside the piece of cheese, where it had ingested most of the dothiepin which had been left out for it. She has since continued her own prescribed doses of medication, but is somewhat wary of the possible side-effects it may have.

This case indicates the potential toxicity of dothiepin in small mammals! It is an interesting alternative use for a well tried preparation.

Alan Byrne Sile McGauran

James Connolly Memorial Hospital Blanchardstown, Dublin, 15

\section{Hooligans - everybody's problem}

\section{DeAR SiRS}

There has been great concern shown by the media recently on the apparent increase in hooliganism, especially football hooliganism abroad. The hooligan has been around for a long time but hooliganism on such a large scale, sometimes planned, organised and executed by fans in a foreign country, has only recently become such a worrying problem. The question everybody is asking is why? Why is it happening? Why are they doing this? Who are they, and what are their motives? Clearly we need to know the answer to these questions before we can begin to think of a solution. The best way of finding out would be to ask the hooligan. Prior to 1960 the development and testing of delinquency theory depended almost exclusively on official delinquency statistics. Police and court statistics have limitations as measures of delinquent behaviour and self-reported checklists of delinquency have emerged as alternative measures. ${ }^{1,2,3,4}$

Psychoanalysts will suggest to us that there are instinctual aggressive feelings in people and that these feelings are repressed. Although this view may go some way into helping us understand delinquency and aggressive behaviour, it seems to be an acceptance of the problem rather than an inspiration to look for solutions. ${ }^{5}$

'Strain' theorists will maintain that experiences of limited or blocked opportunities lead to a perceived anomie or alienation and an active seeking out of alternative groups and settings in which particular patterns of delinquent behaviour are acquired and reinforced by social learning. ${ }^{6,7,8,9}$

'Control' theorists of delinquency would treat the socialisation process and commitment to conventional norms and values as problematic (failure to internalise conventional norms)..$^{10,11}$

West was able to show from a prospective study in which he followed-up over 400 eight year old boys to the age of 25 that delinquent acts were commonplace. A third of the sample had acquired a conviction record by the time they had reached their 25 th birthday. A minority of individuals went on to become repeat offenders or recidivists and they committed a majority of the offences. These individuals were much more likely to have started offending at a younger age and to have acquired a greater frequency of offences at a younger age, to have a very disadvantaged background such as poor parental attitudes and one or both parents to have had a history of conviction as an adult. ${ }^{12}$

What can be done to stop hooliganism? Does punishment have a positive effect? Some predict that offenders dealt with lightly should get worse while those dealt with more harshly should improve. Van der Haag (1975): "Delinquents are the products of 